\title{
JÁNOS KORNAI, AND NEOCLASSICAL VERSUS INSTITUTIONAL ECONOMICS
}

\author{
József MÓCZÁR
}

János Kornai rejected the relevance of Walrasian equilibrium and considered only disequilibrium states to be compatible with reality in his Anti-Equilibrium. His research was guided by the belief that reality and theory should form an integral unit. Neoclassical economists did not accept his anti-equilibrium theory, which motivated Kornai to relentlessly provide additional evidences. The article follows this exciting and noble struggle from a new perspective in the context of scientific theory.

Keywords: general equilibrium, disequilibrium, anti-equilibrium theory, neoclassical and institutional economics, Newtonian dynamics, system paradigm

JEL classification indices: B1, C, D5, E13, E14

\section{THE START OF A WORLD-FAMOUS RESEARCH}

János Kornai was practically thrust into the limelight of Hungarian economics and the scientific community by his candidate's (PhD) thesis in 1957, which boldly criticized the over-centralized economic governance of the Hungarian communist state. It was fortunate and decisive for his subsequent academic career that his dissertation was published two years later by Oxford University Press, one

József Móczár, Professor at Corvinus University of Budapest, Department of Mathematical Economics and Analysis. E-mail: jozsef.moczar@uni-corvinus.hu 
of the world's leading academic publishers. Kornai's Hungarian language dissertation got at the right time and in the best of hands (under the care of Anthony de Jasay ${ }^{1}$ and then John Hicks) to get translated and then published. Until then, the only economics book Kornai had earnestly studied was Marx's The Capital. Marx's book is not an easy read; it assumes familiarity with the theories of classical economists such as Smith, Ricardo, Malthus, etc., whose political economics he harshly criticized while developing his own theory. However, it is a testimony to Kornai's talent that he wrote a dissertation based solely on his reading of Marx, which captured the attention of both the reputable English publisher and Western academic circles.

The sharp critique of The Capital vis-à-vis political economy served as a map for Kornai in writing his first book. The success of the dissertation was due to his sincere and courageous exploration of the Hungarian reality of the time, which also resulted in his break with Marxism. He intuitively recognized that Western academic circles were mostly interested in what was happening in Eastern Europe, in what was going on beyond the Iron Curtain, and did not fall into the error that many domestic economists (unsuccessful mathematicians) cannot avoid even today: copying Western theories and mathematical models only, but without Western economic knowledge. After giving up Marxism, he decided to belong to the Western economics profession (Kornai 2006: 123). At the same time, he clearly saw that he could only be a successful researcher if he examined the socialist system through Western eyes and mathematical methods. A few years later, this approach was already evidenced by his articles, his papers co-authored with Tamás Lipták on the mathematical analysis of the profitability of socialist firms (1962), and the two-level formulation of the long-term planning tasks of the national economy (1965).

Both of these articles were originally written in Hungarian and were shortly afterwards published in English in Econometrica, which bolstered Kornai's ambition for further research, ${ }^{2}$ eventually earning him fame in the field of mathematical economics as well.

1 Anthony de Jasay (Antal Jászay) is an economist and liberal philosopher of Hungarian origin living in France at present. For details see Kornai (2005: 109).

2 I felt similar to what Kornai experienced at the time in the early 1990s when two of my articles were published - one of them as a leading paper - in Metroeconomica, which also helped me to earn a $\mathrm{PhD}$ degree in Economics at Osaka University, ISER. 


\section{ANTI-EQUILIBRIUM: COINCIDENCE OF REALITY AND THEORY}

In his distinctive explanation of economic systems theory and general equilibrium theory, Kornai (1968) noted that this particular article would soon be followed by a more extensive research report, which was published three years later under the title Anti-Equilibrium: On Economic Systems Theory and the Tasks of Research (Kornai 1971b). According to Kornai (2006: 197), and I tend to agree with him, this was the most ambitious of all of his research projects to date. A more complete solution to the critical issues raised in Anti-Equilibrium (hereinafter AE) was taking shape, to some extent, throughout his interim research before it was summed up in his most recent book (Kornai 2013), where his critical observations of AE regarding the Arrow-Debreu (1954) model - General Equilibrium (hereinafter GE) - were also supported by statistical data and facts.

Before AE, he published an analysis on the pressure and suction phenomena on the market (Kornai 1971a) which, two years later, was followed by an article written jointly with mathematician Béla Martos (Kornai - Martos 1973) on the autonomous control of economic systems. These two articles were less to the liking of the profession, and he later acknowledged that this line of research was not convincing enough for others.

Kornai's book from 1972 contains pre-AE research that was ultimately left out from AE. It is a fairly eclectic topic, covering the Soviet Union's forced growth during the era of planned economy in the 1920s, and subsequently confronting the model of capitalist countries' theoretical, long-term, efficient growth in the 1960s and 1970s - the so-called turnpike theories, etc. - with the harmonious growth of sectors. ${ }^{3}$ Similarly to Kornai's all previous publications, this work clearly shows that he was only willing to model economic reality with realism and moral values. Because of this ars poetica, he voluntarily and intentionally confronted with the mainstream neoclassical economics school. (The details of this are discussed later in the paper.)

$\mathrm{AE}$ was received by unusually divisive criticism, which Kornai experienced as a failure. The sharpest criticism was made by Frank Hahn (1973) against AE and in defense of GE. As I have meticulously examined the discussion between Kornai and Hahn both in a Hungarian paper (Móczár 2006) and - with new ideas - in an English study (Móczár 2017a), I shall not cover their debate here. Instead, I place $\mathrm{AE}$ in the broader context of the science theory of American economics.

In essence, I modeled the latter with Jinkichi Tsukui under a reducible structure in Japan's input-output data (Móczár - Tsukui 1992). 


\section{NEOCLASSICAL VERSUS INSTITUTIONAL ECONOMICS}

Just as the US has two major parties, the Democratic Party and the Republican Party, American economics also consists of two major schools, institutional and neoclassical economics.

Institutional economics dominated American economics at least until the 1940s when fleeing from fascism, the many eminent scholars and scientists from Europe moved to America that took a laissez faire approach to English classical and neoclassical works, European culture, and spirit. The researches of the new American generation were mostly built on these works and spirit. "Intellectual giants like Samuelson and Arrow led the way, sweeping away the old, more literary tradition in economics [institutional economics] and attracting a small army of scholars with a more scientific bent” (Blinder 1999: 147). This neoclassical school became the mainstream trend, probably due to its liberal approach and elegance (gained from the application-free pure theory of Russian mathematics) ${ }^{4}$, which is paradoxical, as the relevance of institutional economics lies in solving genuine economic issues. But what are the main characteristics of neoclassical and institutional economics, and how do they differ in their teachings and research?

Neoclassical economics is the intellectual product of the last third of the 19th century and of the 20th century. It relies on abstract assumptions, axiomatic formalism, and mathematics inspired by Newtonian mechanics in exploring and modeling ex ante the instantaneous correlations, and subsequently the deterministic and stochastic dynamics of a non-existent, parallel world. In its dynamic models, it accepts the fatalist intuition of classical economists, a long-term equilibrium independent of the initial conditions, and - in my opinion - incorrectly identifies it with the ergodic hypothesis. Neoclassical economics developed in line with the liberal laissez faire philosophy following the latest achievements of physics and mathematics. The essence of classical economics provided the "core" of its questions for further complex neoclassical studies, also exploiting the latest results of contemporary mathematics and physics. In this sense, the neoclassical theory is merely a new arrangement of instruments, just like Mozart's Haydn transcripts. In some parts of the developed Western world, however, the intellectual market puts the highest value on the consistent results produced by the human mind in this field: this approach is the mainstream and is awarded the Nobel Prize despite the fact that the relevance of its elegant theories is highly

4 The Cowles Commission, the Bourbaki School, and David Hilbert's Axiomatic Mathematics also played an indispensable role in shaping the neoclassical (American) economic thinking. For details, see Móczár (2008). 
questionable in view of its unrealistic assumptions and neo-positive formulations. ${ }^{5}$ The contribution of neoclassical economics to the well-being of humanity is debatable, and in some cases its application has in fact led to global financial and economic crises (Móczár 2017b).

Institutional economics has been pursued since the beginning of the 20th century in the US; until then, American economists followed the doctrines of classical economics. Walton Hamilton (1919: 309-311) argued that institutional economics could integrate economics alone by showing how the parts of the economic system related to the whole, and stressed that it was not defined by normative considerations. Institutional economics attaches importance to the institutional system of the economy and society, to the correlations of law and economics, to regulations, contract and trust issues, and to ex post investigations; its forecasts are surrounded by uncertainties.

The most recent, generally accepted propositions of institutional research are presented by Hodgson (2000): (1) Institutional economists insist on the practical relevance of their theories, but their research is independent from political proposals. (2) The results of psychology, sociology, and anthropology are extensively used in order to develop a richer analysis of human behavior. (3) Studying institutions and the processes, innovations, and changes of institutional behavior is a major task for economists. (4) The subject of research is a natural economy, an open and evolving system affected by technological changes and embedded in a broader set of social, cultural, political, and power relations. (5) Through "reconstructive, downward causation", institutions fundamentally influence all economic actors.

By the end of the 1960s, Kornai's desire to become a part of the Western economics profession and an advocate of neoclassical economics had undoubtedly strengthened. This ambition led to the inception of $\mathrm{AE}$ and also gave rise to numerous controversial statements, such as, "It is my conviction that the further progress of economic theory will depend, if not exclusively at least significantly, on the advances made in the field of mathematical economics" (Kornai 1971b: 4), or "Up to present, economics has produced only a single finished theory describing the operation of the economy from a systems-theoretical point of view. This (...) is called general equilibrium theory and derives from the teachings of Walras" (ibid.: 5). At the same time, he argues that economics is a science of "real sciences" (as opposed to social sciences), whose subject is the explanation of

5 Their assumptions stemmed from the unrealistic assumptions of classical economics. For example, classical economist John Stuart Mill (1844) was convinced that a constant population and constant capital stock, that is, the stationary state of the economy, were needed and were desirable for every economy. 
economic reality (cf. Kornai 1971b: 11). He then goes on to express criticism of GE unequivocally: "Modern mathematical equilibrium theory ... does not satisfy at all ... the principal requirement of a real-science theory ...; its propositions have not been verified. ... both its assumptions and propositions are obviously in conflict with reality. Equilibrium theory is merely an intellectual experiment” (ibid.: 17). At this point of his career, he still considered himself a mathematical economist.

It is praiseworthy that Kornai remained consistent; he broke with Marxism because the Hungarian communist reality gave ample proof that Marxists did not confront their theories with the reality of the socialist systems. While Kornai was absolutely right in his criticism of GE, in the euphoria of his earlier professional successes and showered with accolades and encouragement by his colleagues at Stanford and Yale University before the publication of AE, he failed to realize that owing to its unrealistic assumptions, the neoclassical school to which GE belonged focused its research on the correlations of a non-existent parallel world. The elegance and modern mathematics of neoclassical theory can be attractive and misleading at the same time, even for those who are fully aware of their limitations and the fact that they are completely useless in solving the problems of economic reality. The best example for this is the paradoxical situation in which Samuelson, one of the greatest representatives of neoclassical economics, found himself. As a young man at the age of 20, he clearly recognized and harshly criticized the unrealistic assumptions of neoclassical economics, while later, as a mature scientist, he fully accepted and incorporated the very same assumptions into his models.

"I abstract heroically. We are all exactly alike. We live forever, we are perfect competitors and all-but-perfect soothsayers. Our inelastic labor supply is fully employed, working with inelastically supplied Ricardian land and (possibly heterogeneous) capital goods. We have built-in Pigou-Böhm rates of subjective time preference, discounting each year's independent utility by the constant factor (...). We are in long-run equilibrium without technical change or population growth: the stock of capital goods has been depressed to the point where all own-interestrates are equal to $r$, the market rate of interest; in turn, $r$ is equal to the subjective interest rate $\rho$, this being the condition for our propensity to consume being 100 per cent of income, with zero net capital formation” (Samuelson 1968: 5).

There is no doubt that Kornai's critical remarks on GE echoed the objectives of institutional economics: ex-post examination, theoretical openness, critical thinking, intellectual sincerity, and emphasis on dynamics and uncertainty. It would require a separate study to trace these points through Kornai's academic career. Needless to say, the neoclassical and institutional schools of economics are sharply opposed to each other. Perhaps this triggered Hahn's harsh criticism (1973) 
against AE. Although many have been deceived by the cheap success of the mainstream, Kornai did not allow himself to be seduced by the elegance of neoclassical economics. He criticized the non-reality of its models, although, as he said in his autobiography, he did not articulate his judgment convincingly enough. His research, books, and articles reflect the creed of institutional economics, even though he never considered himself an institutional economist. ${ }^{6}$

The career of a policy-maker or policy-adviser and a scholar is incompatible - this was Kornai's understanding, when he chose a career in research in June 1955. ' Similarly, no-one can be both a neoclassical and an institutional economist at one and the same time. Being a follower of institutional economics does not mean that one must break with the ideology and ideals of capitalism. It has been shown that until 2005, nearly as many institutional economists were awarded the Nobel Prize as neoclassical economists, which suggests that the scientific prestige of the first approach is not inferior (Móczár 2017b). The now-fashionable "heterodox" classification ${ }^{8}$ does not blur the lines between the neoclassical and institutional schools; it is essentially institutional and multidisciplinary, and it refutes the theories of the neoclassical school with more mathematics.

\section{DISEQUILIBRIUM A LA KORNAI AND ITS EVIDENCE}

Instead of the static GE, Kornai interpreted GE as a stationary model ${ }^{9}$, which, as we shall see, enabled him to introduce its specific balances. The stationary model formulates a temporal constancy on a system; we can say that it is a system describing the equilibrium state of a dynamic model. (If the authors examine stochastic dynamics, they refer to a stationary process ${ }^{10}$.) If a system is in a stationary state, it will stay there until the end of times, unless there is an external

6 In 2005, my manuscript, the “Arrow-Debreu model and Kornai critique”, characterized Kornai as an ex post economist, which was vigorously contested by one of his close mathematician academic associates. I accepted his objection and eventually dimmed the ex post approach in the article (Móczár 2006). I knew, however, that the ex ante approach contradicts Kornai’s academic aspiration: the coincidence of reality and theory.

7 The career change had been proposed by a Hungarian friend, Miklós Gimes somewhat earlier, around 1952-53: "Politics is not the thing for you. You would do better if you became a researcher; it would suit you better” (Kornai 2006: 73).

8 See Editorial (2016).

9 Kornai (1971b) explained that GE could be a stationary model employing Samuelson's theory of revealed preference (Samuelson 1947). However, as Stanley Wong (1978) pointed out, the Samuelson theorem was misleading. Here I use Newtonian dynamics.

10 Within a stochastic process, we can speak of a stationary process: a stochastic process where the distribution functions are the same in the case of arbitrary time shifts in test times. 
shock. This conceptual clarification also tells us how to build a stationary model from a dynamic model. The technique is as simple as possible: in the case of a discrete time model, the difference between the two consecutive time values of the variable is taken to zero, while in a continuous case, any instantaneous change in the variable is eliminated from the system. This eliminated the dynamics of the model that determined the system's instantaneous equilibrium state.

Based on this, the definition of the static model is also clear: an equation or equations in which the "variables" in the correlations are not dependent on time; i.e. the "variables" are unknown. (Some researchers, for example, Richard H. Goodwin, considered the general equilibrium model to be a simple equation system.) It is important to emphasize that these models are by no means tied to dynamics. This does not mean that we cannot allocate time to the unknowns. But if we do, only the same moment of time can be assigned to all unknowns, which is why many textbooks view the static state as a momentary state, a "snapshot" of the economy. In this sense, we can also say that the static model, if the equation system is solved, always captures a momentary equilibrium state.

It can be seen from the above that the static model and the stationary model describe a state and an emphasized equilibrium in accordance with the equilibrium paradigm of the mainstream neoclassical school. This gives rise to a number of new questions: is the static model different from the stationary one, and if so, to what extent? The answer is that essentially there is no difference, but the stationary model, as it comes from a dynamic system, allows us to study the behavior of the economy in non-equilibrium situations. And this leads to the latest paradigm of today's modern theoretical economics: how does the economy behave in nonequilibrium situations? This approach, albeit indirectly, is also rooted in game theory since Nash (1953) formulated the co-operative game as the equilibrium point of the non-cooperative game.

GE uses Walras' definition to define equilibrium: demand is equal to supply. In AE, Kornai diverges from this definition: depending on the systems, he defines equilibrium as states of permanent disequilibrium. The equilibrium of capitalism is an asymmetric state of excess-supply, the equilibrium of socialism is an asymmetric state of excess-demand. The latter is the shortage economy, the real equilibrium state of socialism, while the former is a surplus economy, the real equilibrium state of capitalism. Kornai (2006: 189) states with resignation: "The underlying idea of a skewed, asymmetrical state subsisting under both systems superiority either of buyers or sellers - made little headway." He did not attribute this failure to the use of the unusual terms "pressure" and "suction".

Anyone who follows Kornai's research can easily observe his tendency to publish a series of thought experiments and sketches before launching his latest original thought, as if he were probing the academic world to see whether he is on 
the right track. In addition, he has an excellent researcher attitude: he defends his scientific findings with endless perseverance if he is firmly convinced that they are correct. So it was to be expected that in his future works, he would return to the failure of AE, more precisely, to the causes of the failure such as the unusual equilibrium definition of the two systems. His next work (Kornai 1980) examined the equilibrium states, the shortage economy and its causes, and the development of socialism. The Economics of Shortage became a world success: for the first time, the citizens of the socialist countries were given scientific explanations by Kornai (through prices, wages, soft budgets, etc.) to the phenomena depressing their everyday lives. This book was the first station in the further development of the ideas presented in AE. "The reader may be convinced - without proof of concrete references - that Economics of Shortage is in many ways related to AntiEquilibrium and it tries to fulfil a number of research tasks indicated in the earlier book" (Kornai 1980: 13).

The Economics of Shortage did not examine the political structure and ideology of the socialist system. It was partly a deliberate compromise and partly the course announced at Harvard University that motivated Kornai to write his book The Socialist System: The Political Economy of Communism. It is based on the most salient feature of the political sphere, the predominance of the communist party. "In that sense, I was finally able to write genuine political economy" (Kornai 2006: 333). At the time of writing this book, Kornai was already a fullyfledged institutional economist: the political economy of socialism was studied from the perspective of sociology, social psychology, and political philosophy, while illuminating how the building-blocks of the socialist system fit together. He called his approach to the system a paradigm. Until then, Kornai wrote in a neoclassical theoretical framework, but in this work, he embraced the approach of institutional economics. Despite garnering numerous accolades and becoming Kornai's most frequently cited work, the book did not become a world success and received severe criticism for the sudden shift between schools.

The other persistent state of disequilibrium - the surplus economy of capitalism, its real state of equilibrium, as Kornai calls it - is a less understood concept in $\mathrm{AE}$. This was the final concept that needed to be formulated in more detail than the somewhat ambiguous explanation offered in AE. By then, Kornai had lived in the US for 10 years as a full professor at Harvard University, so he had had ample opportunity to gain experience and insight into the capitalist system. For this project, the sketches were provided by his book Gondolatok a kapitalizmusról (Thoughts on Capitalism) published in 2011. The first two chapters of the book focus on innovation and dynamism, technical progress, different markets (products and services, workforce), and dynamics, all topics that are not included in GE. The AE-generated professional career path was complete 
when Oxford University Press published his book Dynamism, Rivalry, and the Surplus Economy: Two Essays on the Nature of Capitalism in 2013. As I have already analyzed and compared the DRSE model - defined as an acronym from the book’s title - with other equilibrium schools (Móczár 2015), I shall refrain from further analysis here.

\section{POSTSCRIPT}

In 1993, having won a Giovanni Agnelli scholarship, I was studying Goodwin's models as a guest researcher of the University of Siena, Italy. At that time, the University of Siena was one of the centers of economic dynamics: Richard $\mathrm{H}$. Goodwin, Frank Hahn, Robert Solow, Lionello Punzo, and others taught and researched at the Department of Economics. In our free time, we talked a great deal about modern economics. János Kornai's Anti-Equilibrium had been also brought up in some of the conversations. Evidently, Frank Hahn was still fairly critical of AE. So it was only natural that in 2005, before writing a paper on the debate on AE, I asked him whether his opinion on AE had changed since then. The answer was short and to the point: "It is not too profitable to walk through the glowing embers again." ${ }^{11}$ In defiance of his admonition, I continued my research on the comparison of GE and AE (Móczár 2006), and I ignored it again when writing this article. Personally, I have learnt a great deal from János Kornai’s professional experiences and his economics.

\section{REFERENCES}

Arrow, J. K. - Debreu, G. (1954): Existence of an Equilibrium for a Competitive Economy. Econometrica, 22(3): 265-290.

Blinder, A. S. (1999): Economics Becomes a Science - or does It? In: Bearn, A. (ed.): Useful Knowledge: The American Philosophical Society Millennium Program (Philadelphia: American Philosophical Society): 141-154.

Editorial (2016): A Short Note on “Heterodox Economics”. Journal of Heterodox Economics, 1(2): 100-103.

Hahn, F. (1973): The Winter of Our Discontent. Economica, 40(159): 322-330.

Hamilton, W. H. (1919): The Institutional Approach to Economic Theory. American Economic Review, 9(Supplement): 309-318.

Hodgson, M. G. (2000): What is the Essence of Institutional Economics? Journal of Economic Issues, 34(2): 317-329.

Kornai, J. (1959): Overcentralization in Economic Administration: A Critical Analyses Based on Experience in Hungarian Light Industry. London: Oxford University Press.

11 Personal e-mail correspondence. 
Kornai, J. (1968): Anti-Equilibrium. Mimeo, Institute of Economics, Hungarian Academy of Sciences, Budapest.

Kornai, J. (1971a): Nyomás és szívás a piacon (Pressure and Suction on the Market). Közgazdasági Szemle, 18(1): 41-60.

Kornai, J. (1971b): Anti-Equilibrium (On Economic Systems Theory and the Tasks of Research). First edition: Amsterdam: North-Holland Publishing Company. Reprinted in 1991 by Augustus M. Kelley, Fairfield NJ.: Publishers.

Kornai, J. (1972): Rush versus Harmonic Growth. Amsterdam: North-Holland Publishing Company.

Kornai, J. (1980): Economics of Shortage. Amsterdam: North-Holland Publishing Company.

Kornai, J. (1992): The Socialist System. The Political Economy of Communism. Princeton: Princeton University Press; Oxford: Oxford University Press.

Kornai, J. (2006): By Force of Thought. Irregular Memoirs of an Intellectual Journey. Cambridge, MA: MIT Press.

Kornai, J. (2013): Dynamism, Rivalry, and the Surplus Economy (Two Essays on the Nature of Capitalism). Oxford: Oxford University Press.

Kornai, J. - Lipták, T. (1962): A Mathematical Investigation of Some Economic Effects of Profit Sharing of Socialist Firms. Econometrica, 30(1): 140-161.

Kornai, J.- Lipták, T. [1965]: Two-Level Planning. Econometrica, 33(1): 141-169.

Kornai, J. - Martos, B. (1973): Autonomous Control of the Economic System. Econometrica, 41(3): 509-528.

Mill, J. S. (1844): Essays on Some Unsettled Questions of Political Economy. London: John W. Parker.

Móczár, J. (2006): Arrow-Debreu model és a Kornai kritika 30 év után (Arrow-Debreu Model and Kornai Critics after 30 Years). Közgazdasági Szemle, 53(2): 175-194.

Móczár, J. (2008): Fejezetek a modern közgazdaság-tudományból. Sztochasztikus és dinamikus nemegyensúlyi elméletek, természettudományos közelitések (Chapters from Modern Economic Theory, Stochastic and Dynamic Nonequilibrium Theories, Scientific Approaches). Budapest: Akadémiai Kiadó.

Móczár, J. (2015): Kornai’s DRSE Theory versus General Equilibrium Theory. Public Finance Quarterly, State Audit Office of Hungary, 60(2): 194-211.

Móczár, J. (2017a): Arrow-Debreu Model versus Kornai-Critique. Athens Journal of Business and Economics, 3(2):143-169.

Móczár, J. (2017b): Ergodic versus Financial Processes, Part II. Neoclassical and Institutional Economics. Public Finance Quarterly, State Audit Office of Hungary (forthcoming).

Móczár, J. - Tsukui, J. (1992): Balanced and Unbalanced Growth Paths in a Decomposable Economy: Contributions to the Theory of Multiple Turnpike. Economic Systems Research, 3(1): 211-222.

Nash, J. F. (1953): Two-Person Cooperative Games. Econometrica, 21(1): 128-140.

Samuelson, P. A. (1968): What Classical and Neoclassical Monetary Theory Really Was. The Canadian Journal of Economics, 1(1): 10-15.

Samuelson, P. A. (1947): Foundations of Economic Analysis. Cambridge, MA.: Harvard University Press.

Wong, S. (1978): Foundation of Paul Samuelson's Revealed Preference Theory: A Study by the Method of Rational Reconstruction. London: Routledge. 